\title{
Czy współpraca się opłaca? Wpływ koalicji z Niemcami na sukces Polski w procesie legislacyjnym Unii Europejskiej
}

\begin{abstract}
Streszczenie: Celem artykułu jest analiza, czy zawieranie koalicji z Niemcami wpływa na sukces Polski w procesie legislacyjnym UE. Przetestowano dwie hipotezy: 1) jeśli preferencje Polski oraz Niemiec są zgodne, to sukces Polski jest większy; 2) koalicja z Niemcami zapewnia Polsce większy sukces w obszarach o szczególnym znaczeniu dla Warszawy, to jest: w rolnictwie, energii, środowisku, sprawach wewnętrznych oraz wspólnym rynku. Hipotezy przetestowano za pomocą metody ilościowej - regresji liniowej na bazie DEU II. Uzyskano następujące wnioski. Po pierwsze, budowanie koalicji polsko-niemieckiej w UE jest niezmiernie skomplikowane ze względu na wyraźną sprzeczność preferencji obu państw. Po drugie, mimo to budowanie koalicji z Niemcami jest dla Polski niezmiernie opłacalne. Analiza wykazała, że gdy Polska zawiera sojusz z Niemcami, to jej sukces w procesie legislacyjnym UE widocznie wzrasta. Po trzecie, zawiązywanie koalicji z Niemcami jest szczególnie opłacalne w politykach UE, które są kluczowe z punktu widzenia interesów Polski, czyli w rolnictwie, energii, sprawach wewnętrznych oraz wspólnym rynku. Jedynym wyjątkiem jest obszar ochrony środowiska.
\end{abstract}

Słowa kluczowe: Unia Europejska, negocjacje, proces legislacyjny UE, relacje Polski i Niemiec w UE, koalicja Polski i Niemiec, sukces negocjacyjny

\section{Wstęp $^{1}$}

C elem artykułu jest analiza opłacalności dla Polski współpracy z Niemcami w Unii Europejskiej. Spróbowano odpowiedzieć na pytanie: czy i jak zawieranie koalicji przez Polskę z Niemcami wpływa na sukces tego pierwszego państwa w procesie legislacyjnym UE. Zawieranie koalicji zdefiniowano jako prezentowanie lub wypracowanie przez oba państwa zgodnego stanowiska w negocjacjach nad kwestią legislacyjną. W artykule przetestowano dwie hipotezy. Pierwsza: jeśli preferencje Polski oraz Niemiec w sprawie danej kwestii są zgodne, to sukces Polski jest istotnie większy. Druga: koalicja z Niemcami zapewnia Polsce większy sukces w negocjacjach nad regulacjami z obszarów o szczególnym znaczeniu dla Warszawy, to jest: rolnictwa, energii, środowiska, spraw wewnętrznych oraz wspólnego rynku.

Jak dotychczas, relacje Polski i Niemiec w Unii Europejskiej były przedmiotem licznych badań (Koszel, 2008, 2009; Malinowski, 2015; Węc, 2015, 2016a, 2016b, 2017; Czachór, Marcinkowski, 2017). W kontekście procesu legislacyjnego podejmowano $\mathrm{w}$ ich ramach problematykę m.in. różnic i zgodności preferencji obu państw w poszczególnych obszarach czy możliwości wzajemnej współpracy i budowania wspólnego sta-

${ }^{1}$ Badania zawarte w tym artykule zostały sfinansowane ze środków Polsko-Niemieckiej Fundacji na rzecz Nauki w ramach projektu „Rozbieżność czy wspólnota interesów? Relacje polsko-niemieckie w instytucjach i w procesie legislacyjnym Unii Europejskiej”. 
nowiska. Większość z tych studiów ma charakter historyczny, opisowy lub jest opartych na badaniach jakościowych. Brakuje natomiast opracowań empirycznych bazujących na analizie statystycznej, które wskazywałyby w oparciu o duże zbiory danych (aktów prawnych), czy, kiedy i w jakich obszarach budowanie koalicji z Niemcami jest dla Polski opłacalne lub nie, a więc $w$ jakich warunkach zapewnia Warszawie większy lub mniejszy sukces w negocjacjach legislacyjnych UE. Celem artykułu jest wypełnienie tej luki.

Struktura artykułu składa się z pięciu części. W pierwszej postawiono dwie hipotezy dotyczące wpływu koalicji z Niemcami na sukces Polski. W drugiej omówiono metodologię testu hipotez. Następnie w rozdziale trzecim przeprowadzono opisową analizę statystyczną sukcesu Polski, natomiast w czwartym omówiono rezultaty statystycznego testu hipotez. W konkluzjach podsumowano uzyskane wnioski.

\section{Ramy teoretyczne}

W Unii Europejskiej akty ustawodawcze są uchwalane w ramach tzw. procedur legislacyjnych. Po wejściu w życie Traktatu z Lizbony wyróżnia się dwie takie procedury. Pierwszą i najważniejszą jest zwykła procedura ustawodawcza (ZPU). Polega ona na przyjmowaniu rozporządzeń, dyrektyw i decyzji przez Parlament Europejski wspólnie z Radą na wniosek Komisji Europejskiej. Formalny przebieg ZPU jest ściśle określony w art. 254 TFUE. Natomiast druga procedura uchwalania aktów ustawodawczych UE - specjalna procedura ustawodawcza (SPU) - polega na przyjmowaniu rozporządzeń, dyrektyw i decyzji ,przez Parlament Europejski z udziałem Rady lub przez Radę z udziałem Parlamentu Europejskiego" (art. 289 ust. 1-2 TFUE). W procedurze tej występuje nierównowaga międzyinstytucjonalna - jedna z instytucji, głównie Rada, posiada pozycję dominująca. W praktyce SPU może mieć kilka wariantów, z których najczęściej spotykane to zgoda, konsultacja i procedura uchwalania budżetu.

Według teorii modelowania przestrzennego (Hörl, Warntjen, Wonka, 2005; Crombez, Vangerven, 2014), faktyczne negocjacje w omówionych powyżej procedurach odbywają się pomiędzy kilkudziesięcioma aktorami: 28 państwami członkowskimi tworzącymi Radę, Parlamentem i Komisją. Każdy z nich posiada określone preferencje w sprawie legislacji, które są reprezentowane jako punkty w przestrzeni euklidesowej. Inaczej mówiąc, aktor posiada pewne idealne dla niego rozwiązanie legislacyjne wyrażone w określonej skali, a jego (aktora) użyteczność spada wraz z oddalaniem się końcowego wyniku negocjacji od tego idealnego punktu. W modelach przestrzennych Parlament i Komisja są traktowane unitarnie, ponieważ posiadają jedno, własne stanowisko legislacyjne przyjmowane zwykłą lub bezwzględną większością głosów wewnątrz tych instytucji. Zakłada się, że preferencje tych podmiotów są - zgodnie z twierdzeniem o medianowym wyborcy - równe medianie preferencji wszystkich ich członków. Natomiast Rada nie może być zdefiniowana unitarnie, gdyż, po pierwsze, tworzą ją państwa posiadające odmienne preferencje, oraz po drugie, uchwala swoje stanowiska legislacyjne co do zasady kwalifikowaną większością głosów.

W tak zdefiniowanym środowisku decyzyjnym metodą negocjowania aktów prawnych jest budowanie koalicji między aktorami. Aktorzy o bliskich sobie preferencjach 
próbują tworzyć sojusze, aby zbudować odpowiednią większość dla stanowiska najbardziej dla nich użytecznego. Szczególne znaczenie ma tworzenie tzw. mniejszości blokującej. Jest to określona liczbowo grupa państw, która może uniemożliwić uchwalenie danego aktu prawnego. W świetle badań empirycznych zbudowanie mniejszości blokującej zapewnia jej członkom większy sukces, gdyż wymusza na pozostałych aktorach koncesje, bez których akt prawny nie może być uchwalony (Warntjen, 2017).

Jeśli budowanie koalicji ma znaczenie, to pojawia się pytanie: z kim Polska powinna zawiązywać sojusze, aby zwiększyć swoją skuteczność w procesie legislacyjnym UE? W niniejszym artykule postawiono hipotezę, według której sukces Polski wzrasta, jeśli państwo to zawiązuje koalicję z Niemcami. Zawiązywanie koalicji jest rozumiane jako prezentowanie identycznego, podobnego lub wspólnie uzgodnionego stanowiska w sprawie kwestii legislacyjnej będącej przedmiotem negocjacji w UE. Powyższe twierdzenie bazuje na dwóch argumentach. Po pierwsze, Niemcy są najbardziej liczącym się aktorem z punktu widzenia siły głosu w Radzie. Według badań opartych na tzw. indeksach siły państwo to ma matematycznie największy wpływ na końcowy kształt aktów prawnych, jak i możliwość zablokowania negocjacji w tej instytucji (Nurmi, Meskanen, Pajala, 2013; Barr, Passarelli, 2009). Ta siła decyzyjna jeszcze bardziej wzrosła po ustanowieniu systemu podwójnej większości przez Traktat z Lizbony (Kleinowski, 2015). Jeśli zatem Polska ma po swojej stronie tak silnego aktora, to jej pozycja oraz sukces negocjacyjny powinny znacznie wzrastać.

Po drugie, budowa koalicji polsko-niemieckiej zwiększa szansę na utworzenie tzw. mniejszości blokującej w Radzie. W nicejskim systemie potrójnej większości mogły ją ustanowić państwa posiadające łącznie 90/321 (w okresie 2004-2006), 91/345 (2007-2013) oraz 93/352 (2013-2017) głosów (Węc, 2012, s. 571). Polska i Niemcy dysponowały w tym okresie 56 głosami ważonymi, co oznacza, że potrzebowały już tylko 34-37 głosów do zablokowania decyzji. Ponadto, system nicejski przewidywał fakultatywny warunek, zgodnie z którym decyzja mogła być zablokowana, jeśli państwa ją popierające nie reprezentowałyby $62 \%$ ludności UE. Populacja Polski i Niemiec stanowiła wówczas ok. 24,8\% ludności UE. W efekcie oba państwa potrzebowały wsparcia krajów reprezentujących tylko 13,21\% ludności UE, aby zablokować decyzję. Z kolei w obecnie funkcjonującym systemie podwójnej większości ustanowionym przez Traktat z Lizbony mniejszość blokująca może być utworzona, gdy aktowi prawnemu sprzeciwiają się: 1) cztery państwa reprezentujące więcej niż 35\% ludności UE; 2) 45\% (obecnie 13 państw) ${ }^{2}$ lub 28\% (obecnie 8 państw) ${ }^{3}$ wszystkich członków Rady. Według Regulaminu Rady, Polska i Niemcy posiadają 23,4\% całej ludności UE (Decyzja Rady, 2014). To oznacza, że koalicja polsko-niemiecka potrzebuje do zablokowania decyzji wsparcia już tylko dwóch państw reprezentujących 11,61\% ludności UE. Reasumując: H1: Sukces Polski w procesie legislacyjnym UE jest większy, jeśli państwo to zawiera koalicję z Niemcami.

Według teorii modelowania przestrzennego preferencje aktorów w UE cechują się odmienną intensywnością (Thomson, Stokman, Achen, König, 2006; König, Junge, 2009; Veen, 2011). Inaczej mówiąc, różnią się one w zależności od materii oraz wagi negocjo-

\footnotetext{
2 Dla projektów przedstawionych przez Komisję Europejską lub Wysokiego Przedstawiciela.

${ }^{3}$ Dla projektów przedstawionych przez inne podmioty niż KE lub Wysokiego Przedstawiciela.
} 
wanej kwestii. Regulacje z danego obszaru mogą być ważniejsze dla jednego aktora, gdyż dotykają jego żywotnych interesów, podczas gdy dla drugiego mają mniejsze znaczenie. Racjonalni aktorzy stosują technikę wymiany - koncentrują swoje zasoby negocjacyjne na kwestiach dla nich najważniejszych, próbując uzyskać w nich najlepsze rezultaty, kosztem spraw o relatywnie mniejszej wadze (Crombez, 2000). W tym kontekście budowa koalicji z Niemcami powinna zapewniać Polsce większy sukces w sprawach szczególnie istotnych dla Warszawy. W takich kwestiach Polska jest bardziej zdeterminowana, aby nie tylko taką koalicję zbudować (np. poprzez wspieranie Niemiec w sprawach dla nich ważnych w zamian za ich poparcie dla kwestii kluczowych dla Polski), ale również zapewnić jej odpowiednią siłę (poprzez zastosowanie różnych technik negocjacyjnych), stabilność oraz wsparcie ze strony innych aktorów (dokooptowanie innych aktorów). W niniejszej analizie do spraw o szczególnym znaczeniu dla Polski zaliczono regulacje z zakresu pięciu polityk UE: 1) rolnictwa ze względu na wysoki udział tego sektora w gospodarce Polski; 2) środowiska oraz 3) energii z powodu wysokiej emisyjności gospodarki polskiej, dużego udziału paliw kopalnych w strukturze energetycznej, jak i znacznych różnic interesów Polski i państw „starej” UE w tym obszarze; 4) spraw wewnętrznych z racji dużego znaczenia bezpieczeństwa dla obywateli Polski oraz 5) wspólnego rynku ze względu na szerokie korzystanie z czterech swobód UE przez polskie przedsiębiorstwa (np. usługi transportowe), jak i kosztową konkurencyjność polskiej gospodarki. Reasumując:

H2: Sukces Polski jest większy w kluczowych dla tego państwa politykach UE, takich jak rolnictwo, środowisko, energia, sprawy wewnętrzne oraz wspólny rynek, jeśli państwo to zawiera w nich koalicję z Niemcami.

\section{Metodologia}

Powyższe hipotezy zweryfikowano w oparciu o następująca metodologię. W pierwszym kroku skonstruowano bazę danych. $\mathrm{W}$ drugim kroku dokonano operacjonalizacji zmiennych zależnych, niezależnych i kontrolnych. W trzecim kroku przeprowadzono statystyczny test hipotez przy użyciu regresji liniowej wielorakiej. Poniżej omówiono każdy z tych etapów.

Konstrukcja bazy danych

Do testu hipotez wykorzystano bazę DEU II (Decision-Making in the European Union) zaprojektowaną przez Roberta Thomsona i jego współpracowników (Thomson $i$ in., 2012). Zawiera ona informacje o 331 najbardziej konfliktowych kwestiach legislacyjnych, które pojawiły się w czasie negocjowania 125 najważniejszych aktów prawnych UE. Regulacje te zostały wyselekcjonowane w oparciu o trzy kryteria: czasu (zostały zaproponowane i były negocjowane w latach 1999-2009), ważności (do bazy wprowadzono akty, o których była co najmniej pięciozdaniowa wzmianka w serwisach „Agence Europe” lub „European Voice”") oraz procedury legislacyjnej (wzięto pod uwagę regulacje

${ }^{4}$ Agence Europe jest to działający od 1953 r. brukselski serwis informacyjny poświęconym UE, który jest szczególnie czytany przez urzędników instytucji UE. Z kolei „European Voice” był to tygo- 
uchwalone we współdecydowaniu oraz konsultacji). Następnie autorzy bazy przeprowadzili 349 wywiadów pól-ustrukturyzowanych z ekspertami Parlamentu Europejskiego, Komisji Europejskiej, stałych przedstawicielstw państw członkowskich w Brukseli, Sekretariatu Generalnego Rady oraz grup interesów, którzy brali udział w negocjowaniu tych aktów prawnych. Ich zadaniem była identyfikacja kluczowych konfliktowych kwestii legislacyjnych, które wynikły w czasie negocjowania danego aktu, określenia w skali od 0 do 100 stanowisk wszystkich państw członkowskich, PE i Komisji w odniesieniu do każdej takiej kwestii, a także podanie w tej samej skali końcowego wyniku negocjacji nad daną kwestią. Przy czym wartość 0 miała oznaczać stanowisko najmniej radykalne, podczas gdy wartość 100 miała informować o najbardziej skrajnej preferencji w danej kwestii (Thomson i in., 2012, s. 607-612).

Schemat nr 1 prezentuje praktyczne zastosowanie DEU II. Zawiera on rozkład preferencji i wynik negocjacji nad jedną z kwestii, które pojawiły się w toku uchwalania tzw. dyrektywy powrotowej (Dyrektywa, 2008). Regulacja ta była procedowana we współdecydowaniu w latach 2005-2008. Jej celem było ustalenie norm i procedur dotyczących powrotu i wydalenia obywateli państw trzecich, którzy nielegalnie przebywają na terytorium państw członkowskich UE. Jedną z konfliktowych kwestii było ustalenie okresu, w którym osoby te - w przypadku ryzyka ucieczki lub unikania czy utrudniania przygotowania do powrotu lub wydalenia - moga przebywać w ośrodku detencyjnym (odosobnienia). Jak pokazuje schemat nr 1, aktorzy byli podzieleni w tej kwestii wzdłuż dwóch koalicji. Koalicja dwunastu państw, w skład której wchodziły kraje o dużej sile głosu - Polska, Hiszpania, Francja i Włochy, wspierana dodatkowo przez Komisję Europejska, postulowała, aby ten okres był dość krótki i wynosił maksymalnie 3 miesiące z możliwością rozszerzenia w uzasadnionych przypadkach do 6 miesięcy (pozycja 30 w skali $0-100$ ). W opozycji była grupa dziesięciu państw na czele z Niemcami, ale też składająca się z mniejszych krajów będących pod dużą presją imigracyjną, np. Malty, Grecji, Cypru czy Szwecji. Koalicja ta chciała, aby okres detencji wynosił maksymalnie 18 miesięcy czy nawet nie był określony (pozycje 80 i 100). Outsiderem w tych negocjacjach był Parlament Europejski, który - jako instytucja dbająca o ochronę praw człowie$\mathrm{ka}$ - postulował najkrótszy, zaledwie jednomiesięczny okres odosobnienia, ale był w tym żądaniu osamotniony (pozycja 0). Ostatecznie negocjacje zakończyły się kompromisem (pozycja 90), który zakładał, że maksymalny okres zastosowania środka detencyjnego nie może przekroczyć sześciu miesięcy. Mógł być on jednak wyjątkowo przedłużony o kolejne dwanaście miesięcy, jeżeli wydalenie miało potrwać dłużej ze względu na: brak współpracy ze strony obywatela państwa trzeciego lub opóźnienia w uzyskiwaniu dokumentacji z państwa trzeciego (art. 15 dyrektywy).

Analizując schemat 1, można stwierdzić, że największymi wygranymi negocjacji były Niemcy oraz państwa o małej sile głosu (Austria, Cypr, Estonia, Grecja i Litwa), gdyż końcowy wynik był zaledwie o 10 punktów oddalony od ich stanowiska. Drugi w kolejności rezultat osiągnęły Szwecja, Finlandia, Malta i Łotwa (różnica 30 punktów). Natomiast - mimo posiadania silnej pozycji formalnoprawnej w procedurze współdecydowania - największym przegranym był Parlament Europejski, gdyż odległość między jego stanowiskiem a wynikiem była największa - 70 punktów.

dnik zajmujący się sprawami UE, który został w 2015 r. kupiony przez joint venture Politico i Axela Springera. Obecnie ukazuje się pod zmienionym tytułem „Politico Europe”. 
Schemat 1. Stanowiska aktorów w sprawie maksymalnego okresu detencji nielegalnych imigrantów z państw trzecich (COD/2005/167)

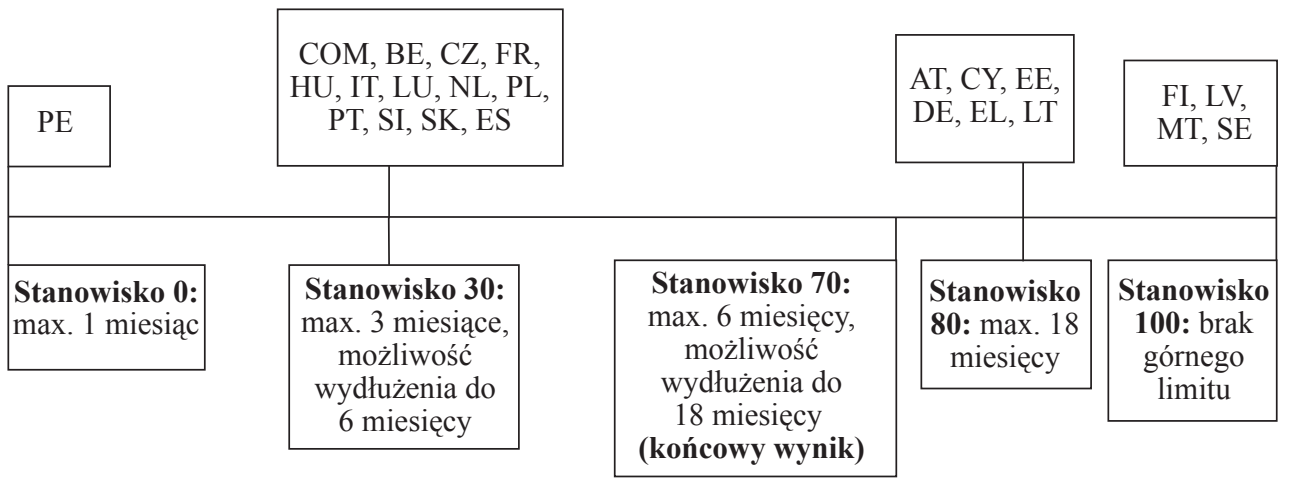

Skróty: PE - Parlament Europejski, COM - Komisja Europejska, AT - Austria, BE - Belgia, CY - Cypr, CZ - Czechy, DE - Niemcy, DK - Dania, EE - Estonia, EL - Grecja, ES - Hiszpania, FI - Finlandia, FR - Francja, HU - Węgry, IE - Irlandia, IT - Włochy, LT - Litwa, LU - Luksemburg, LV - Łotwa, MT - Malta, NL - Holandia, PL - Polska, PT - Portugalia, SE - Szwecja, SI - Słowenia, SK - Słowacja, UK - Wielka Brytania.

Źródło: Baza DEU II, Thomson i in., 2012.

Baza DEUII jest przedmiotem pewnej krytyki w literaturze. Zwraca się przede wszystkim uwagę, że, po pierwsze, zawiera ona tylko projekty najbardziej kontrowersyjne, po drugie, większość przepytywanych decydentów pochodzi z przedstawicielstw państw członkowskich oraz, po trzecie, decydenci byli przepytywani już po uchwaleniu aktu prawnego, a więc mieli motywację, aby raportować większy sukces swoich państw. Mimo to, liczne testy wykazały, że DEUII jest reprezentatywna oraz wiarygodna pod względem naukowym (Thomson i in., 2006; König i in., 2007; Leinaweaver, Thomson, 2014). W efekcie jest ona powszechnie wykorzystywana $\mathrm{w}$ literaturze do badań empirycznych (zob. Costello, Thomson, 2011, 2013; Aksoy, 2012; König, Junge, 2009; Kreppel, Oztas, 2017).

\section{Operacjonalizacja zmiennych}

W oparciu o bazę DEU II dokonano operacjonalizacji zmiennych. I tak, zmienną zależną w badaniu jest „Sukces Polski”. Jest ona wyrażona w skali 0-100 jako wartość bezwzględna odległości między stanowiskiem/preferencją Polski a końcowym wynikiem negocjacji w sprawie danej kwestii legislacyjnej. Poziom sukcesu Polski będzie obliczony za pomocą następującego wzoru:

$$
\text { Sukces }_{P L}=\mid \text { Preferencja }_{P L}-\text { Wynik } \mid
$$

gdzie: Sukces ${ }_{P L}$ - sukces Polski wyrażony w skali 0-100;

Preferencja $_{P L}$ - preferencja/stanowisko Polski w sprawie danej kwestii legislacyjnej wyrażona w skali $0-100$;

Wynik - końcowy wynik negocjacji nad daną kwestią (0-100). 
Analiza równania prowadzi do wniosku, że im wyższa jest wartość zmiennej zależnej $\left(\right.$ Sukces $\left._{P L}\right)$, tym większa odległość między preferencją Polski a końcowym wynikiem negocjacji, a więc tym mniejszy sukces Polski. Przy czym wartość 0 oznacza całkowity sukces, czyli idealną zgodność stanowiska Polski i końcowego wyniku, podczas gdy 100 informuje o całkowitej porażce, czyli największej możliwej odległości między końcowym wynikiem a stanowiskiem Polski w danej kwestii.

W celu weryfikacji $H 1$ skonstruowano zmienną ilościową ciągłą o nazwie „Niemcy”. Informuje ona, jaki był poziom zgodności (w wartościach bezwzględnych) w skali 0-100 stanowisk Polski oraz Niemiec w sprawie kwestii. Wartość 0 oznacza, że preferencje tych państw były identyczne, podczas gdy wartość 100 informuje o całkowitej sprzeczności stanowisk. Im zatem wyższa wartość zmiennej „Niemcy”, tym większa niezgodność preferencji tych aktorów.

H2 stanowiła, że budowanie koalicji z Niemcami zapewnia Polsce większy sukces w kluczowych dla tego państwa politykach UE. Aby to zweryfikować, skonstruowano dwie grupy zmiennych. Pierwsza określa materię negocjowanego projektu. Została ona określona według formacji Rady, w której prowadzono negocjacje nad projektem. W tej grupie skonstruowano pięć zmiennych fikcyjnych o nazwach:

1) Rolnictwo (projekty negocjowane w Radzie ds. Rolnictwa i Rybołówstwa - AGRIFISH);

2) Środowisko (projekty negocjowane w Radzie ds. Środowiska - ENVI);

3) Energia i Transport (projekty negocjowane w Radzie ds. Transportu, Telekomunikacji i Energii - TTE);

4) Sprawy Wewnętrzne (projekty negocjowane w Radzie ds. Sprawiedliwości i Spraw Wewnętrznych - JHA);

5) Wspólny Rynek (projekty negocjowane w Radzie ds. Konkurencyjności-COCOM). Każda z nich wynosi 1 - jeśli projekt był negocjowany w danej formacji Rady właściwej ze względu na materię projektu, albo 0 - jeśli projekt był rozpatrywany w innej Radzie. Formację Rady ustalono dla każdego projektu na podstawie Rejestru Publicznego Rady 5

Druga grupa zmiennych składa się z interakcji zmiennej Niemcy oraz wyżej opisanych predyktorów określających materię projektu. Skonstruowano pięć takich interakcji: 1) Niemcy*Rolnictwo, 2) Niemcy*Środowisko, 3) Niemcy*Energia i Transport, 4) Niemcy*Sprawy Wewnętrzne, 5) Niemcy*Wspólny Rynek. Ich celem jest sprawdzenie, czy i jaki wpływ ma koalicja Berlina i Warszawy na sukces Polski w poszczególnych obszarach materialnych.

Analizę uzupełniono o jedną zmienną kontrolną - Parlament Europejski. Ma ona postać ilościową ciaggłą i mierzy poziom zgodności preferencji Polski i Parlamentu Europejskiego. Mówiąc szczegółowiej, odzwierciedla ona w skali 0-100 odległość (w wartościach bezwzględnych) między stanowiskami tych aktorów w sprawie danej kwestii legislacyjnej. Im bliżej rzeczona zmienna jest wartości 0, tym większa zgodność Polski i PE. I vice versa - im dalej od zera, tym mniejsza spójność preferencji tych aktorów.

${ }^{5}$ Przy operacjonalizacji tych zmiennych nie brano pod uwagę formacji Rady, która formalnie uchwaliła finalne stanowisko legislacyjne tej instytucji, gdyż bardzo często zdarza się, że z racji oszczędności czasu inna formacja Rady głosuje nad końcowym stanowiskiem, a inna go wcześniej negocjuje (ta jest ważniejsza). 
Uwzględnienie w analizie Parlamentu Europejskiego wynika z faktu, że według badań empirycznych Parlament ma - pod pewnymi warunkami - kluczowy wpływ na finalny kształt aktów prawnych UE w ZPU i SPU (Costello, Thomson, 2011; Kirpsza, 2015; Kirpsza, 2016b). W efekcie poziom zgodności stanowisk Polski i PE może mieć istotne znaczenie dla sukcesu tego państwa.

\section{Regresja liniowa wieloraka}

Ponieważ zmienna zależna ma postać ilościową ciaggła, najlepszą metodą weryfikacji hipotez jest regresja liniowa wieloraka (Fox, 2008). Jest to technika statystyczna, która pozwala modelować zależności liniowe między zmienną zależną a zmiennymi niezależnymi (predyktorami), określić istotność statystyczną tych relacji, a także dokonać predykcji. Mówiąc precyzyjniej, jej celem jest oszacowanie wartości oczekiwanej zmiennej $Y$ (czyli poziomu sukcesu Polski) na podstawie znanych wartości predyktorów $X$ (czyli czynników wpływających na ten sukces zawartych w hipotezach). Regresję liniową wieloraką można opisać następującym równaniem:

$$
Y_{i p}=\alpha+\beta_{j} X_{j i p}+\varepsilon_{i p}
$$

gdzie: $Y_{i p}$ - zmienna zależna: sukces Polski, średnia odległość między stanowiskiem Polski a końcowym wynikiem negocjacji nad kwestią legislacyjną $i$ zawartą w projekcie $p$;

$\alpha-$ wyraz wolny, stała;

$\beta$ - współczynnik kierunkowy regresji liniowej;

$X_{i p}$ - zmienne niezależne: wartość danego predyktora dla kwestii legislacyjnej $i$ zawartej w projekcie $p$;

$j$ - kolejne numery współczynników i predyktorów;

$\varepsilon_{i p}-$ błąd losowy.

Obliczenia regresyjne przeprowadzono na bazie DEUII, która została zredukowana do projektów negocjowanych po wejściu Polski do UE, a więc w latach 2004-2009. Aby rozwiązać problem hierarchiczności obserwacji, modele regresji liniowej zostały oszacowane za pomocą tzw. odpornych i sklastrowanych błędów standardowych (Cameron, Miller, 2015).

\section{Sukces Polski w UE - opisowa analiza statystyczna}

Wykres nr 1 prezentuje poziomy sukcesu państw członkowskich oraz dwóch aktorów instytucjonalnych - Parlamentu oraz Komisji w procesie legislacyjnym UE. Obrazuje on średnie odległości w skali 0-100 między preferencjami danego aktora a końcowym wynikiem negocjacji nad kwestiami legislacyjnymi w latach 2004-2009. Im mniejsza ta odległość, tym większy sukces aktora. 


\section{Wykres 1. Sukces aktorów w procesie legislacyjnym UE}

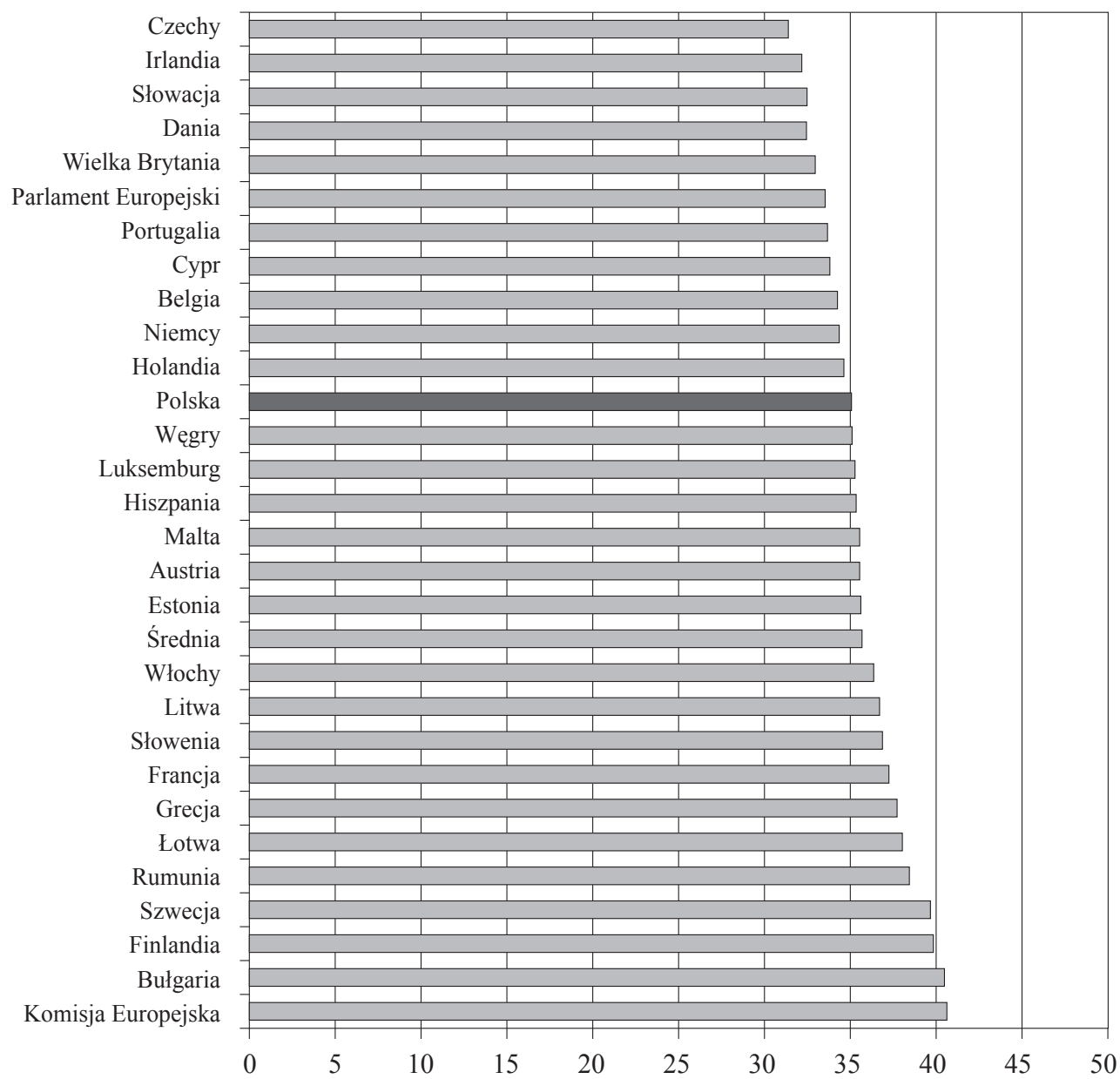

Źródło: Obliczenia własne na podstawie bazy DEUII, Thomson i in., 2012.

Z wykresu 1 wynika, że w badanym okresie stanowisko Polski było oddalone od końcowego wyniku negocjacji o średnio 35 punktów, co daje temu państwu 12 miejsce przy zestawieniu wszystkich aktorów. Można uznać, że rezultat ten nie jest satysfakcjonujący, biorąc pod uwagę szóste miejsce Polski pod względem siły głosu i populacji w Radzie. Ale sukces Niemiec jest prawie na tym samym poziomie. W latach 2004-2009 preferencje Berlina były oddalone od końcowego wyniku o średnio 34 punkty w skali 0-100. Wynik ten daje Niemcom 10 miejsce, co również jest rezultatem słabym w świetle posiadania przez to państwo największej siły głosu spośród członków Rady. Wbrew zatem powszechnemu przekonaniu, Niemcy nie są dominującym oraz najbardziej skutecznym aktorem w procesie legislacyjnym UE.

Sukces Polski może jednak różnić się w zależności od materii negocjowanej regulacji. Dlatego narysowano wykres 2 prezentujący średni poziom sukcesu Polski w 10 obszarach materialnych zdefiniowanych według formacji Rady, w której negocjowano 
dany projekt. Poziom sukcesu jest tutaj mierzony średnią odległością między stanowiskiem Polski a końcowym wynikiem negocjacji nad projektami zaliczonymi do danego obszaru. Im większa ta odległość, tym mniejszy sukces legislacyjny.

Wykres 2. Sukces Polski oraz zgodność preferencji Polski i Niemiec ze względu na materię negocjowanego aktu prawnego

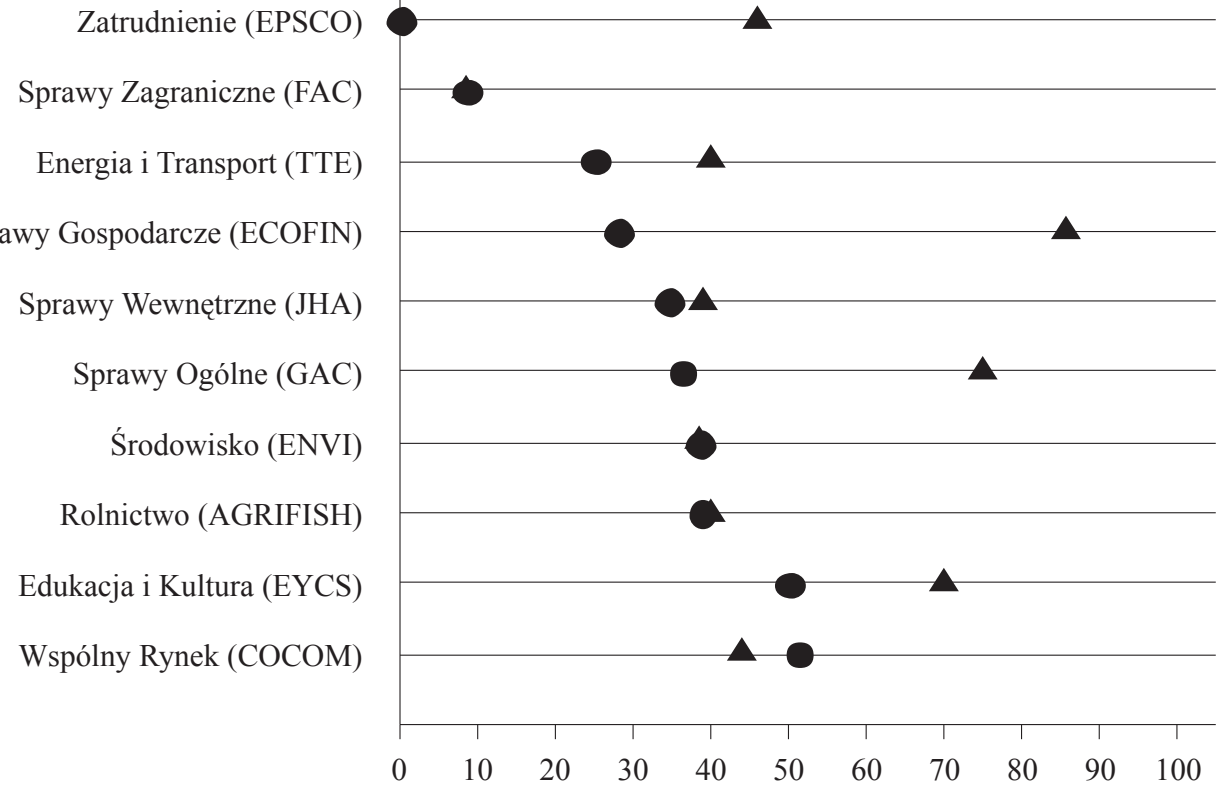

mean of Sukces_Polski $\mathbf{\Delta}$ mean of Zgodność_Polski_i_Niemiec

Źródło: Opracowanie własne na podstawie Thomson i in., 2012.

W badanym okresie Polska osiaggała największy sukces w negocjowaniu projektów dotyczących zatrudnienia i spraw zagranicznych. W obszarach tych zidentyfikowano najniższą średnią odległość między preferencjami Polski a końcowym wynikiem - kolejno 0 oraz 8 punktów. W bazie DEUII znalazły się 3 kwestie dotyczące zatrudnienia i w każdej z nich Polsce udało się uzyskać rezultat idealnie zgodny ze swoim stanowiskiem. Zauważalne są również dobre wyniki w obszarach energii i transportu (25 punktów) oraz spraw gospodarczych (28 punktów). W obu tych politykach średnia odległość między stanowiskiem Polski a finalnym wynikiem negocjacji była widocznie niższa od średniej dla wszystkich kwestii (35 punktów). Pewnym zaskoczeniem jest obecność w tym gronie regulacji z zakresu energetyki. Powszechnie uważa się, że Polska słabo sobie radzi w negocjacjach w tym sektorze. Analiza pokazuje jednak coś odwrotnego, przy czym trzeba dodać, że w obszarze tym uwzględniono również projekty z zakresu transportu oraz telekomunikacji, które mogą zaburzać powyższy wniosek.

Natomiast najgorsze rezultaty legislacyjne Polska uzyskiwała w latach 2004-2009 w przypadku regulacji dotyczących edukacji i kultury oraz wspólnego rynku. W sekto- 
rach tych zaobserwowano największe średnie odległości między preferencjami Polski a końcowym wynikiem negocjacji - kolejno 51 i 50 punktów. W pozostałych obszarach sukces Polski oscylował wokół średniej odległości dla wszystkich projektów wynoszącej 35 punktów.

Drugą kwestią wartą analizy jest zgodność preferencji Polski i Niemiec. Czy i na ile zbieżne są stanowiska tych państw w sprawie kwestii legislacyjnych negocjowanych w UE? Odpowiedź na to pytanie jest kluczowa z punktu widzenia realnych możliwości budowania koalicji przez Polskę i Niemcy w procesie legislacyjnym UE. Im bowiem bliżej siebie są ich preferencje, tym większe są możliwości wypracowania i prezentowania wspólnego stanowiska w negocjacjach. W celu zbadania tego problemu narysowano wykres nr 3, który obrazuje średnie odległości między stanowiskami Polski a wszystkimi państwami członkowskimi, a także Komisją i Parlamentem.

Z wykresu wynika wniosek, że mimo geograficznej bliskości oraz wielu wspólnych interesów Polskę i Niemcy cechuje olbrzymia niezgodność preferencji w procesie legislacyjnym UE. W badanym okresie stanowisko Polski było średnio o ok. 43 punkty oddalone od pozycji Niemiec w skali $0-100$. Jest to wynik, który sytuuje Niemcy jako ostatniego - nie licząc Komisji i PE - partnera oraz największego konkurenta Polski, posiadającego najbardziej odmienne preferencje ze wszystkich państw członkowskich. Co jednak istotne, ten sam wniosek dotyczy Polski, jeśli przyjąć perspektywę Niemiec. Jak pokazuje wykres 3, w rankingu najbliższych koalicjantów tego państwa Polska znajduje się na trzecim od końca miejscu, nie licząc PE i KE. Wynik ten wskazuje nie tylko na wielkie rozbieżności interesów obu krajów w procesie legislacyjnym UE, ale również na poważne trudności w ich godzeniu i budowaniu wspólnej koalicji.

Choć ogólna zgodność Polski i Niemiec jest niska, to może ona - podobnie jak sukces Polski - różnić się w zależności od materii negocjowanego projektu. Aby to sprawdzić, na wykresie 2 umieszczono średnie odległości między stanowiskami tych państw w 10 obszarach zdefiniowanych według formacji Rady, w której dany projekt był negocjowany. Z wykresu 2 wynika, że Polska i Niemcy mają najbardziej zbieżne preferencje w sprawach zewnętrznych UE. Średnia odległość między stanowiskami wyniosła tutaj zaledwie 8 punktów w skali $0-100$. Wynik ten nie jest zaskoczeniem. W literaturze podkreśla się, że mimo pewnych rozbieżności, np. w polityce wschodniej czy stosunku do Rosji, Polska i Niemcy posiadają w miarę zgodne interesy w polityce zagranicznej (Malinowski, 2015, s. 131-159; Koszel, 2008, s. 217-223; Węc, 2016b).

Natomiast największą rozpiętość preferencji zaobserwowano w trzech obszarach: sprawy gospodarcze, sprawy ogólne (np. kwestie instytucjonalne) oraz edukacja i kultura. Polityki te wyraźnie odstają od pozostałych, cechując się średnią niezgodnością stanowisk na poziomie powyżej 70 punktów w skali 0-100. Pewnym zaskoczeniem jest obecność w tym gronie edukacji i kultury. W literaturze podkreśla się bowiem głęboką współpracę w tym obszarze, zwłaszcza po 2007 r. (Koszel, 2009; Węc, 2016a). Trzeba jednak zauważyć, że w bazie DEUII są najbardziej konfliktowe kwestie, które w przypadku obszaru edukacji i kultury dotyczyły regulacji sektora nadawców telewizyjnych. Z kolei rozbieżność interesów w sprawach ogólnych, zwłaszcza dotyczących reformy ustrojowej UE czy działań instytucjonalnych zwalczających kryzys w strefie euro, jest zauważana w literaturze (Węc, 2017). 
Wykres 3. Zgodność preferencji Polski, Niemiec oraz poszczególnych aktorów

Koalicjanci Polski

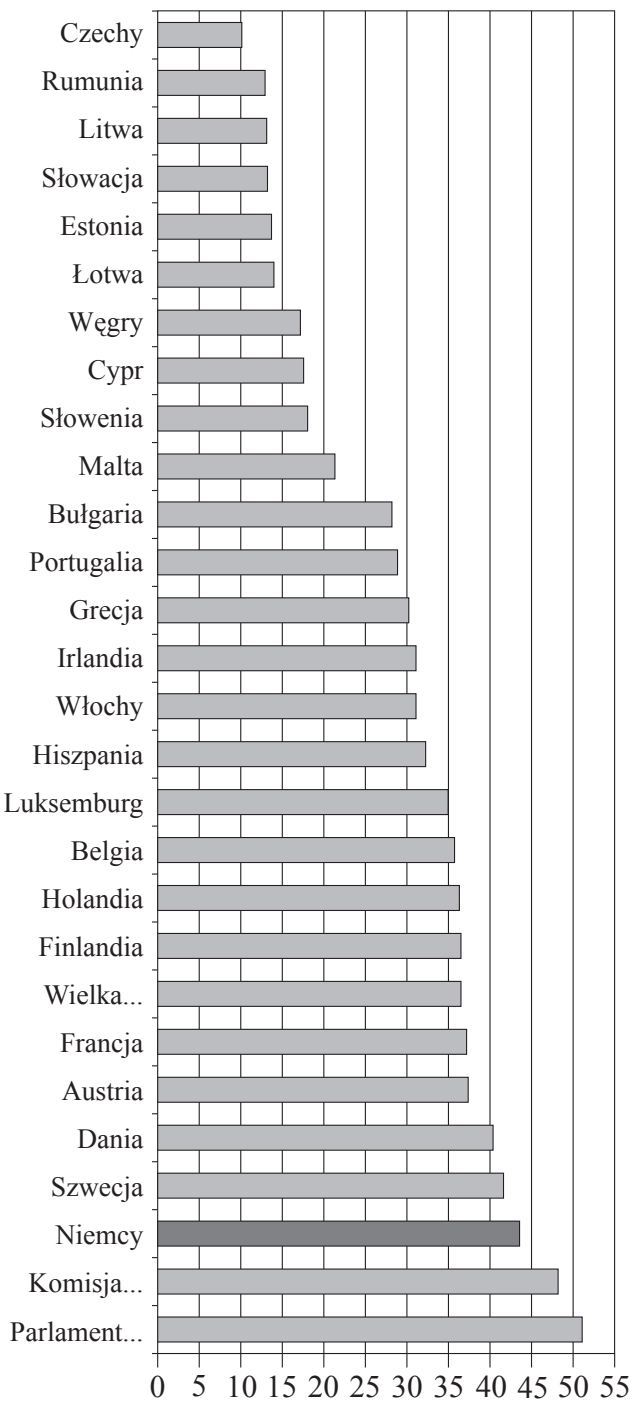

Koalicjanci Niemiec

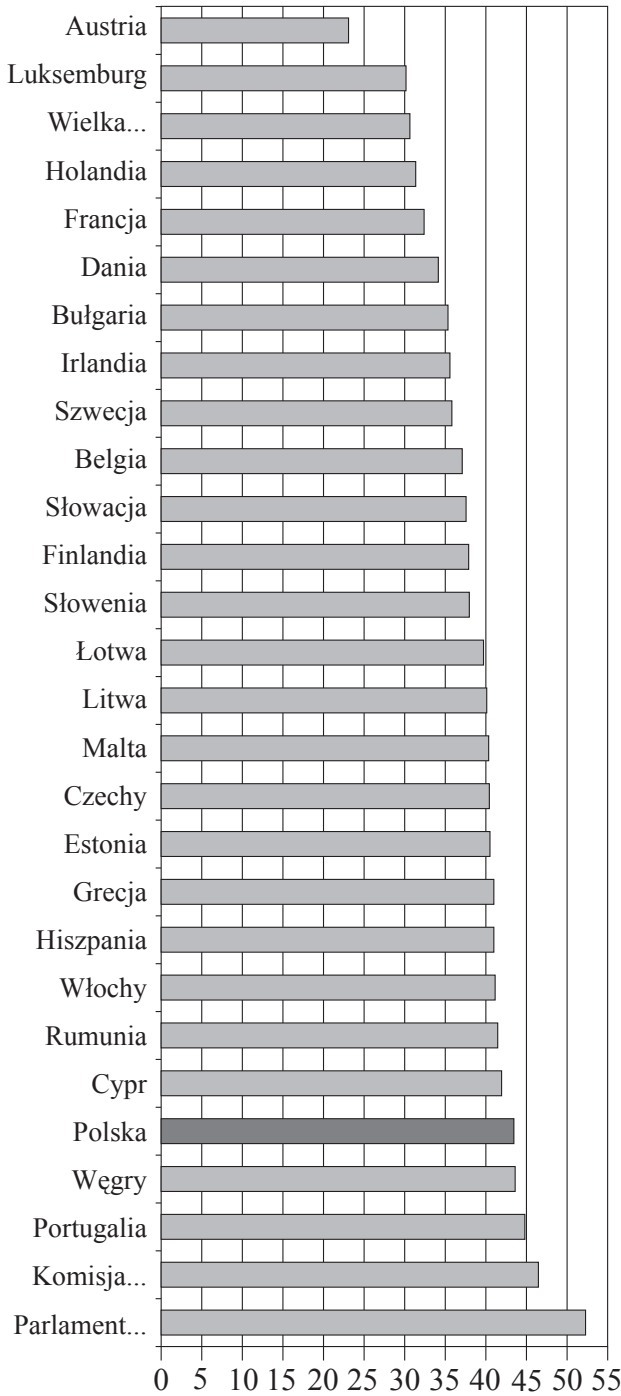

Źródło: Obliczenia własne na podstawie bazy DEUII, Thomson i in., 2012.

W pozostałych obszarach zgodność preferencji Polski i Niemiec oscylowała wokół średniej, w przedziale 40-50 punktów w skali 0-100. Odległość ta wskazuje jednak na dużą rozbieżność interesów obu państw w tych kwestiach. Dotyczy to zwłaszcza polityk o szczególnym znaczeniu dla Polski, takich jak rolnictwo, sprawy wewnętrzne, energetyka, ochrona środowiska czy wspólny rynek. Powyższa obserwacja potwierdza zresztą wyniki badań jakościowych pokazujących obecność dużego konfliktu preferencji Polski i Niemiec w tych obszarach (Malinowski, 2015; Węc, 2015; BojenkoIzdebska, 2016). 


\section{Sukces Polski w UE - weryfikacja hipotez}

Tabela 1 prezentuje wyniki regresji liniowej wielorakiej. Oszacowano cztery modele. Model 1 zawiera tylko jeden predyktor - Niemcy. Jego celem jest przetestowanie wyłącznie $H 1$ oraz sprawdzenie, jaki jest samodzielny wpływ tej zmiennej na sukces Polski. W modelu 2 umieszczono sześć predyktorów: Niemcy, Rolnictwo, Środowisko, Energia i Transport, Sprawy Wewnętrzne oraz Wspólny Rynek. Model 3 uzupełnia model 2 o pięć interakcji: Niemcy*Rolnictwo, Niemcy*Środowisko, Niemcy*Energia i Transport, Niemcy*Sprawy Wewnętrzne oraz Niemcy*Wspólny Rynek. Zgodnie ze wskazaniami zawartymi w literaturze, w modelu tym umieszczono zarówno interakcje, jak i wszystkie predyktory je tworzące (Brambor, Clark, Golder, 2006). Jego celem jest przetestowanie $H 2$ oraz sprawdzenie, czy i jak koalicja z Niemcami wpływa na sukces Polski w tych kluczowych obszarach. Model 4 dodaje natomiast do modelu 3 jedną zmienną kontrolną - Parlament Europejski, aby uwzględnić ewentualny wpływ preferencji tej instytucji na sukces Polski.

Tabela 1

Wyniki regresji liniowej wielorakiej - zmienna zależna: sukces Polski

\begin{tabular}{|c|c|c|c|c|}
\hline & Model 1 & Model 2 & Model 3 & Model 4 \\
\hline Niemcy & $\begin{array}{c}0,262^{* *} \\
(0,084)\end{array}$ & $\begin{array}{l}0,292^{* * *} \\
(0,077)\end{array}$ & $\begin{array}{l}0,252^{* * *} \\
(0,069)\end{array}$ & $\begin{array}{l}0,212^{* * *} \\
(0,062)\end{array}$ \\
\hline Rolnictwo & $\begin{array}{l}- \\
-\end{array}$ & $\begin{array}{c}20,35^{* * *} \\
(4,522)\end{array}$ & $\begin{array}{l}12,13^{* *} \\
(3,752)\end{array}$ & $\begin{array}{c}8,482 \\
(8,986)\end{array}$ \\
\hline Środowisko & $\begin{array}{l}- \\
-\end{array}$ & $\begin{array}{l}20,63^{* * *} \\
(4,546)\end{array}$ & $\begin{array}{c}29,98^{* * *} \\
(3,752)\end{array}$ & $\begin{array}{l}23,48^{* *} \\
(9,866)\end{array}$ \\
\hline Energia i Transport & - & $\begin{array}{c}6,720 \\
(4,520)\end{array}$ & $\begin{array}{c}1,787 \\
(3,752)\end{array}$ & $\begin{array}{c}4,510 \\
(8,931)\end{array}$ \\
\hline Sprawy Wewnętrzne & $\begin{array}{l}- \\
- \\
-\end{array}$ & $\begin{array}{l}16,15^{* * *} \\
(4,519)\end{array}$ & $\begin{array}{l}13,70^{* * *} \\
(3,752)\end{array}$ & $\begin{array}{c}6,607 \\
(9,931)\end{array}$ \\
\hline Wspólny Rynek & $\begin{array}{l}- \\
- \\
-\end{array}$ & $\begin{array}{c}31,72^{* * *} \\
(4,464)\end{array}$ & $\begin{array}{l}19,89^{* * *} \\
(3,752)\end{array}$ & $\begin{array}{c}27,98^{* * *} \\
(8,465)\end{array}$ \\
\hline Niemcy*Rolnictwo & $\begin{array}{l}- \\
-\end{array}$ & $\begin{array}{l}- \\
-\end{array}$ & $\begin{array}{c}0,185^{* *} \\
(0,069)\end{array}$ & $\begin{array}{l}0,251^{* * *} \\
(0,062)\end{array}$ \\
\hline Niemcy*Środowisko & $\begin{array}{l}- \\
-\end{array}$ & $\begin{array}{l}- \\
-\end{array}$ & $\begin{array}{c}-0,267^{* * *} \\
(0,069)\end{array}$ & $\begin{array}{c}-0,164^{* *} \\
(0,063)\end{array}$ \\
\hline Niemcy*Energia i Transport & $\begin{array}{l}- \\
-\end{array}$ & $\begin{array}{l}- \\
-\end{array}$ & $\begin{array}{c}0,103 \\
(0,069)\end{array}$ & $\begin{array}{c}0,166^{* *} \\
(0,062)\end{array}$ \\
\hline Niemcy*Sprawy Wewnętrzne & $\begin{array}{l}- \\
-\end{array}$ & $\begin{array}{l}- \\
-\end{array}$ & $\begin{array}{c}0,040 \\
(0,069)\end{array}$ & $\begin{array}{c}0,223^{* * *} \\
(0,066)\end{array}$ \\
\hline Niemcy*Wspólny Rynek & $\begin{array}{l}- \\
-\end{array}$ & $\begin{array}{l}- \\
-\end{array}$ & $\begin{array}{c}0,254^{* * *} \\
(0,069)\end{array}$ & $\begin{array}{c}0,149^{*} \\
(0,066)\end{array}$ \\
\hline Parlament Europejski & $\begin{array}{l}- \\
-\end{array}$ & $\begin{array}{l}- \\
-\end{array}$ & - & $\begin{array}{l}0,279^{* * *} \\
(0,046)\end{array}$ \\
\hline Stała & $\begin{array}{c}23,22^{* * *} \\
(4,235)\end{array}$ & $\begin{array}{c}6,597 \\
(5,997)\end{array}$ & $\begin{array}{c}9,009^{* *} \\
(3,752)\end{array}$ & $\begin{array}{l}-5,248 \\
(8,016)\end{array}$ \\
\hline$R^{2}$ & 0,111 & 0,193 & 0,235 & 0,352 \\
\hline AIC & 1194,3 & 1182,5 & 1175,8 & 1037,5 \\
\hline BIC & 1200,0 & 1188,1 & 1181,4 & 1045,6 \\
\hline $\mathrm{N}$ (kwestie legislacyjne) & 124 & 124 & 124 & 112 \\
\hline $\mathrm{N}$ (projekty) & 52 & 52 & 52 & 49 \\
\hline $\mathrm{N}$ (formacje Rady) & 10 & 10 & 10 & 10 \\
\hline
\end{tabular}

Objaśnienia: ${ }^{*} p<0,1 ;{ }^{* *} p<0,05 ;{ }^{* * *} p<0,01$. W nawiasach są sklastrowane i odporne błędy standardowe. 
Przechodząc do testu hipotez, analiza empiryczna potwierdziła $H 1$. Zgodnie z przewidywaniem, budowanie koalicji z Niemcami, rozumiane jako posiadanie lub uzgadnianie wspólnego stanowiska, zapewnia Polsce wyraźnie wyższy poziom sukcesu w procesie legislacyjnym UE. Informuje o tym współczynnik $\beta$ zmiennej Niemcy, który jest dodatni $\mathrm{i}$ istotny statystycznie. Wynik ten można interpretować w dwojaki sposób. Po pierwsze, im większa jest niezgodność preferencji Polski i Niemiec, tym większa jest odległość między stanowiskiem Polski a końcowym wynikiem negocjacji w sprawie danej kwestii legislacyjnej, a więc tym mniejszy jest sukces Polski. Po drugie, im bardziej preferencje obu państw są zbieżne, tym mniejsza jest ta odległość, a więc tym większy jest sukces Polski. Z modelu 2 wynika, że, utrzymując pozostałe zmienne na stałym poziomie, wzrost odległości preferencji Polski i Niemiec o 10 punktów w skali 0-100 prowadzi do zmniejszenia sukcesu Polski o ok. 3 punkty w tej samej skali (zwiększenia odległości między stanowiskiem Polski a końcowym wynikiem negocjacji o ok. 3 punkty). Ponadto, analiza wykazała, że same relacje z Niemcami w procesie legislacyjnym UE są bardzo ważnym predyktorem pozycji negocjacyjnej Polski. Świadczy o tym fakt, że w modelu 1 zmienna Niemcy samodzielnie wyjaśnia $11 \%$ wariancji sukcesu Polski, co stanowi ok. 1/3 wariancji modelu zawierającego wszystkie zmienne (model 4). Reasumując, z wyników analizy empirycznej wyłania się wniosek, że Polska powinna współpracować z Niemcami i dążyć do wypracowania z nimi wspólnego stanowiska w sprawie legislacji. Taka taktyka zapewnia bowiem Warszawie większe prawdopodobieństwo sukcesu w procesie legislacyjnym UE.

H2 również została potwierdzona. Większa zgodność preferencji Polski i Niemiec pozytywnie wpływa na sukces tego pierwszego państwa w politykach UE kluczowych dla Warszawy. Efekt ten jest widoczny w czterech z pięciu zakładanych obszarów. Po pierwsze, koalicja z Niemcami zapewnia Polsce większy sukces w obszarze rolnictwa. Informuje o tym współczynnik interakcji Niemcy*Rolnictwo, który jest dodatni i istotny statystycznie. Ceteris paribus, gdy Polska i Niemcy mają idealnie zgodne preferencje w sprawie kwestii rolniczych, to sukces Polski w tej materii jest o ok. 25 punktów większy w porównaniu do występowania takiej zgodności w pozostałych obszarach. Po drugie, koalicja polsko-niemiecka przekłada się na większy sukces Polski także w dziedzinie energii i transportu. Współczynnik interakcji Niemcy*Energia $i$ Transport jest co prawda nieistotny statystycznie w modelu 3, ale uzyskuje tę istotność po uwzględnieniu wpływu Parlamentu Europejskiego w modelu 4. Siła tego efektu jest mniejsza niż w przypadku rolnictwa, ale wciąż widoczna - idealna koalicja z Niemcami w energetyce zapewnia Polsce większy sukces średnio o ok. 17 punktów w porównaniu do występowania takiej zgodności w pozostałych politykach. Po trzecie, korzyści legislacyjne przynosi również Polsce większa zgodność preferencji z Niemcami w sprawach wewnętrznych. Co prawda, współczynnik interakcji Niemcy*Sprawy Wewnętrzne jest nieistotny statystycznie w modelu 3, ale - podobnie jak poprzednio omawiany predyktor - uzyskuje tę istotność w modelu 4 kontrolującym wpływ Parlamentu Europejskiego. Ceteris paribus, idealnie zgodne stanowisko Polski i Niemiec w regulacjach dotyczących spraw wewnętrznych zapewnia Warszawie średnio ok. 22 punktów większy sukces w porównaniu do występowania takiej zgodności w pozostałych obszarach. Po czwarte, koalicja polsko-niemiecka także pozytywnie wpływa na sukces Polski w obszarze wspólnym rynku i usług. Interakcja Niemcy*Wspólny Rynek jest dodatnia i istotna statystycznie w modelach 3 i 4. 
Wartość współczynnika informuje, że wzrost zgodności preferencji Polski i Niemiec w kwestiach dotyczących wspólnego rynku o każde 10 punktów w skali 0-100 zmniejsza odległość między stanowiskiem Polski a końcowym wynikiem negocjacji o ok. 2 punkty w porównaniu do występowania takiej zgodności w pozostałych obszarach.

Jedynym wyjątkiem niepotwierdzającym $H 2$ jest obszar ochrony środowiska. Analiza empiryczna wykazała, że zawieranie przez Polskę koalicji z Niemcami w tej dziedzinie nie przynosi Warszawie korzyści legislacyjnych. Informuje o tym współczynnik interakcji Niemcy*Środowisko, który jest ujemny i istotny statystycznie. Oznacza to, że większa zgodność preferencji Polski i Niemiec w sprawach środowiskowych nie tylko nie zwiększa sukcesu Polski, ale wręcz przeciwnie - ten sukces redukuje. W tym sensie nie opłaca się współpracować z Niemcami w tym obszarze.

Analiza ujawniła również silny wpływ preferencji Parlamentu Europejskiego na sukces Polski. Współczynnik $\beta$ zmiennej Parlament Europejski jest dodatni i istotny statystycznie w modelu 4. Oznacza to, że im bardziej niezgodne są preferencje Polski i PE, tym większa jest odległość między stanowiskiem Polski a końcowym wynikiem negocjacji nad daną kwestia, a więc tym mniejszy jest sukces Polski. Ceteris paribus, wzrost niezgodności tych dwóch aktorów o każde 10 punktów skutkuje wzrostem tej odległości o prawie 3 punkty. Uzyskany wynik potwierdza pogląd spotykany w literaturze o wpływowej roli PE zarówno w ZPU, jak i SPU (Kirpsza, 2015, 2016b). W tym kontekście polscy posłowie do PE powinni podejmować wszelkie działania, aby Parlament przyjął w głosowaniu plenarnym stanowisko legislacyjne jak najbardziej zbliżone do polskiego. Wówczas Polska może liczyć na silnego koalicjanta.

\section{Konkluzje}

Z przeprowadzonej w niniejszym artykule analizy empirycznej wynikają trzy istotne wnioski na temat możliwości zawierania i opłacalności dla Polski koalicji z Niemcami w procesie legislacyjnym UE. Po pierwsze, budowanie koalicji polsko-niemieckiej w UE jest niezmiernie skomplikowane i, jak dotychczas, było rzadkie lub nieefektywne. Oba państwa mają wyraźnie sprzeczne preferencje w wielu kwestiach, co znacznie utrudnia poszukiwanie wspólnych stanowisk. Analiza wykazała, że pod względem zgodności preferencji Niemcy są ostatnim - nie licząc Komisji i PE - partnerem Polski, posiadającym najbardziej odmienne stanowiska ze wszystkich państw członkowskich. I vice versa, w rankingu najbliższych koalicjantów Niemiec, Polska znajduje się również na ostatnim miejscu. Zgodność preferencji Polski i Niemiec różni się jednak w zależności od materii negocjowanych projektów. Analiza wykazała, że oba państwa mają bardzo zbliżone stanowiska $\mathrm{w}$ sprawach zewnętrznych UE. Natomiast największą rozpiętość preferencji zaobserwowano w trzech sferach: sprawach gospodarczych, ogólnych (np. budżet, kwestie instytucjonalne) oraz w edukacji i kulturze. W pozostałych obszarach - zwłaszcza w rolnictwie, sprawach wewnętrznych, energetyce czy ochronie środowiska - niezgodność stanowisk Polski i Niemiec przekracza 40 punktów w skali 0-100, co również wskazuje na duży konflikt interesów.

Po drugie, mimo znacznej rozbieżności preferencji budowanie koalicji z Niemcami jest dla Polski niezmiernie opłacalne. Analiza empiryczna wykazała, że gdy Polska 
zawiera koalicję z Niemcami, czyli posiada lub wypracowuje z tym państwem zgodne stanowisko w sprawie danej legislacji, to jej sukces w procesie legislacyjnym UE widocznie wzrasta.

Po trzecie, zawiązywanie koalicji z Niemcami jest szczególnie opłacalne w politykach UE, które są kluczowe z punktu widzenia interesów Polski. Analiza wykazała, że zgodność preferencji z Berlinem zapewnia Warszawie większy sukces w negocjacjach nad aktami prawnymi z zakresu rolnictwa, energii, spraw wewnętrznych oraz wspólnego rynku. Jedynym wyjątkiem jest obszar ochrony środowiska, w którym koalicja z Niemcami nie tylko nie przynosi Polsce zysków legislacyjnych, ale wręcz pogarsza jej pozycję.

Reasumując, analiza pokazała, że propozycje prowadzenia przez Polskę polityki unijnej bez współpracy z Niemcami czy nawet przeciwko nim nie są uzasadnione. Takie działanie powoduje zmniejszenie sukcesu Polski. W związku z powyższym wyłaniają się dwie rekomendacje dla Warszawy. Pierwsza brzmi: należy dążyć do niwelacji zaobserwowanej w badaniu olbrzymiej rozbieżności preferencji Polski i Niemiec, aby zapewnić większe możliwości budowania wzajemnej koalicji. Nie jest to zadanie niewykonalne. Jedną z metod jest pakietowanie, czyli popieranie przez Polskę preferencji Niemiec w sprawach legislacyjnych kluczowych dla Berlina, a mniej ważnych dla Warszawy, w zamian za co Niemcy popierałyby preferencje Polski w kwestiach dla niej najważniejszych, a mniej istotnych dla Berlina. Deniz Aksoy (2012) oraz Thomas König i Dirk Junge (2009) wykazali, że aktorzy są bardziej skłonni do zmiany swojego stanowiska właśnie w warunkach pakietowania. W przypadku Polski i Niemiec taka wymiana jest ułatwiona, gdyż oba państwa mają różne intensywności i zakresy preferencji, a w świetle badań empirycznych te cechy znacznie zwiększają szansę na pakietowanie (Kardasheva, 2013). Druga rekomendacja brzmi natomiast: należy w każdym przypadku współpracować z Niemcami i uzgadniać z nimi wspólne stanowisko w sprawie legislacji, gdyż takie działanie przynosi Warszawie pozytywne rezultaty legislacyjne. Oczywiście pojawia się pytanie, czy taka koalicja jest też korzystna dla Niemiec. Ale jest to problem na inne badanie.

\section{Bibliografia}

Aksoy D. (2012), Institutional arrangements and logrolling: Evidence from the European Union, „American Journal of Political Science”, vol. 56, no. 3, s. 538-552.

Barr J., Passarelli F. (2009), Who has the power in the EU?, „Mathematical Social Sciences”, vol. 57, no. 3, s. 339-366.

Bojenko-Izdebska E. (2016), Polityka migracyjna i azylowa w Niemczech i Polsce, „Krakowskie Studia Międzynarodowe", nr 2, s. 43-55.

Brambor T., Clark W. R., Golder M. (2006), Understanding Interaction Models: Improving Empirical Analyses, „Political Analysis”, vol. 14, nr 1, s. 63-82.

Cameron C., Miller D. (2015), A Practitioner's Guide to Cluster-Robust Inference, „Journal of Human Resources", vol. 50, no. 2, s. 317-372.

Costello R., Thomson R. (2011), The nexus of bicameralism: Rapporteurs' impact on decision outcomes in the European Union, „European Union Politics”, vol. 12, no. 3, s. 337-357.

Costello R., Thomson R. (2013), The distribution of power among EU institutions: who wins under codecision and why?, ,Journal of European Public Policy”, vol. 20, no. 7, s. 1025-1039. 
Crombez C. (2000), Spatial models of logrolling in the European Union, „European Journal of Political Economy", vol. 16, no. 4, s. 707-737.

Crombez C., Vangerven P. (2014), Procedural models of European Union politics: Contributions and suggestions for improvement, „European Union Politics”, vol. 15, no. 2, s. 289-308.

Czachór Z., Marcinkowski T. (red.) (2017), Polska - Niemcy - Unia Europejska. Razem czy osobno?, Warszawa.

Decyzja Rady (2014) nr 2014/900/UE z dnia 9 grudnia 2014 r. w sprawie zmiany regulaminu wewnętrznego Rady, Dz. Urz. UE L 358, 13.12.2014, s. 25-27.

Dyrektywa (2008) Parlamentu Europejskiego i Rady 2008/115/WE z dnia 16 grudnia 2008 r. w sprawie wspólnych norm i procedur stosowanych przez państwa członkowskie w odniesieniu do powrotów nielegalnie przebywajacych obywateli państw trzecich, Dz. Urz. UE L 348, 24.12.2008, s. $98-107$.

Fox J. (2008), Applied Regression Analysis and Generalized Linear Models, London.

Hörl B., Warntjen A., Wonka A. (2005), Built on Quicksand? A Decade of Procedural Spatial Models on EU Legislative Decision-Making, „Journal of European Public Policy”, vol. 12, no. 3, s. 592-606.

Kardasheva R. (2013), Package deals in EU legislative politics, „American Journal of Political Science", vol. 57, no. 4, s. 858-874.

Kirpsza A. (2015), Skuteczność poprawek Parlamentu Europejskiego w procedurze konsultacji (specjalnej procedurze ustawodawczej), „Politeja”, nr 3 (35), s. 419-444.

Kirpsza A. (2016a), Jak negocjować w Brukseli? Proces podejmowania decyzji w Unii Europejskiej, Warszawa.

Kirpsza A. (2016b), Warunki sukcesu poprawek Parlamentu Europejskiego w zwyktej procedurze ustawodawczej, „Przegląd Europejski”, nr 2 (40), s. 48-69.

Kleinowski M. (2015), Wpływ Traktatu lizbońskiego na siłę Polski w Radzie Unii Europejskiej, „Myśl Ekonomiczna i Polityczna", nr 1 (48), s. 184-207.

König T., Junge D. (2009), Why Don't Veto Players Use Their Power?, „European Union Politics”, vol. 10, no. 4, s. 507-534.

König T., Lindburg B., Lechner S., Pohlmeier W. (2007), Bicameral conflict resolution in the European Union: An empirical analysis of conciliation committee bargains, „British Journal of Political Science", vol. 37, no. 2, s. 281-312.

Koszel B. (2008), Polska i Niemcy w Unii Europejskiej. Pola konfliktów i płaszczyzny wspótpracy, Poznań.

Koszel B. (2009), „,Nowe otwarcie”? Stosunki polsko-niemieckie w okresie rzqdów koalicji PO-PSL (2008-2009), ,Zeszyty Instytutu Zachodniego”, nr 57.

Kreppel A., Oztas B. (2017), Leading the Band or Just Playing the Tune? Reassessing the AgendaSetting Powers of the European Commission, „Comparative Political Studies”, vol. 50, no. 8, s. $1118-1150$.

Leinaweaver J., Thomson R. (2014), Testing models of legislative decision-making with measurement error: The robust predictive power of bargaining models over procedural models, „European Union Politics", vol. 15, no. 1, s. 43-58.

Malinowski K. (2015), Polska i Niemcy w Europie (2004-2014). Różnice interesów - uwarunkowania i konsekwencje, Poznań.

Nurmi H., Meskanen T., Pajala A. (2013), Calculus of Consent in the EU Council of Ministers, w: Power, Voting and Voting Power: 30 Years After, red. M. Holler, H. Nurmi, Berlin, s. 501-520.

Thomson R., Arregui J., Leuffen D., Costello R., Cross J., Hertz R., Jensen T. (2012), A new dataset on decision-making in the European Union before and after the 2004 and 2007 enlargements, „Journal of European Public Policy”, vol. 19, no. 4, s. 604-622. 
Thomson R., Stokman F., Achen C., König T. (2006), The European Union Decides, Cambridge.

Veen T. (2011), Positions and salience in European Union politics: Estimation and validation of a new dataset, „European Union Politics”, vol. 12, no. 2, s. 267-288.

Warntjen A. (2017), Do votes matter? Voting weights and the success probability of member state requests in the Council of the European Union, „Journal of European Integration”, vol. 39, no. 6, s. $673-687$.

Węc J. (2012), Spór o ksztalt ustrojowy Wspólnot Europejskich $i$ Unii Europejskiej w latach 1950-2010. Między ideq ponadnarodowości a wspótpraca międzyrzqdowa: analiza politologiczna, Kraków.

Węc J. (2015), Relacje polsko-niemieckie w Unii Europejskiej i NATO na poczq̨tku XXI w. Próba bilansu, „Prace Komisji Środkowoeuropejskiej PAU”, t. XXII, s. 117-148.

Węc J. (2016a), Interkulturelle Kommunikation zwischen Polen und Deutschland in der Europäischen Union und ihre Herausforderungen, „Myśl Ekonomiczna i Polityczna”, nr 3, s. 246-275.

Węc J. (2016b), Niemcy w polityce europejskiej Polski w latach 2004-2016, w: Polityka zagraniczna Polski w zmieniajacym się ładzie międzynarodowym: wybrane problemy, red. R. Zięba, T. Pawłuszko, Kielce.

Węc J. (2017), Niemcy wobec reformy ustrojowej Unii Europejskiej w latach 2002-2016, Kraków.

\section{Is cooperation beneficial? The impact of the coalition with Germany on Poland's success in the European Union's lawmaking}

\section{Summary}

The purpose of the article is to analyze whether building a coalition with Germany affects Poland's success in the EU's legislative process. Two hypotheses are tested: (1) when Polish and German preferences are homogenous, Poland's legislative success is greater; (2) the coalition with Germany ensures Poland's greater success in the areas of particular significance to Warsaw, that is in agriculture, energy, environment, home affairs and the single market. The above hypotheses are tested using a quantitative method of a linear regression. Regression calculations are based on the DEU II dataset. The results are as follows. First, forming a Polish-German coalition in the EU's lawmaking is extremely tricky due to strong divergences of both countries' preferences. Second, building a coalition with Germany is particularly beneficial for Poland, nevertheless. The analysis shows that when Poland enters an alliance with Germany, its success in the EU's legislative process significantly increases. Third, building a coalition with Germany is very profitable for Poland in these policy areas which are crucial from the perspective of Poland's interests, namely in agriculture, energy, home affairs and the single market. The only exception is the environment.

Key words: European Union, negotiations, EU's lawmaking, Polish-German relations in the EU, Polish-German coalition, bargaining success 